\title{
Natural Born Citizen as a Requirement of Indonesian President: Significances and Implications
}

\author{
Susi Dwi Harijanti ${ }^{*}$, Firman Manan ${ }^{* *}$, Mei Susanto ${ }^{* * *}$, Ilham Fajar Septian ${ }^{* * * *}$ \\ DOI: https://doi.org/10.22304/pjih.v7n3.a1
}

Submitted: September 30, 2020 | Accepted: December 3, 2020

\begin{abstract}
The Third Amendment to the 1945 Constitution stipulates that one of the requirements to become a presidential candidate is an Indonesian natural-born citizen who has never received another citizenship of his/her own volition. The requirement can create confusion and dissenting opinions to determine persons considered natural-born citizens and methods to prove it. This study explores the significances of determining a natural-born citizen as a requirement to become a presidential candidate and its implications. Through a socio-legal approach, this study concludes that the natural-born citizen requirement's significance is to eliminate racial discrimination from the previous requirement of a "native Indonesian" president and to ensure convincing allegiance from the president. There are some implications of the requirement. First, every Indonesian citizen born after the establishment of the Citizenship Law 2006, regardless of ethnic status, is called a natural-born citizen, including those from mixed marriages and having limited dual citizenship up to the age of 18 years. Meanwhile, for Indonesian citizens born before the Citizenship Law 2006, the naturalborn citizen status is determined based on Law 3 of 1946 and Law 62 of 1958, including Indonesia's agreement with the Netherlands and China. Second, a natural-born citizen status mutatis mutandis should be a requirement of other constitutional positions, either executive, legislative, or judiciary, and to a presidential candidate's husband or wife.
\end{abstract}

Keywords: allegiance, natural-born citizen, presidential requirement.

\section{Natural Born Citizen sebagai Syarat Presiden Indonesia: Arti Penting dan Implikasi}

\begin{abstract}
Abstrak
Amandemen Ketiga UUD 1945 menetapkan salah satu syarat calon presiden adalah kewarganegaraan sejak kelahiran (natural-born citizen) dan tidak pernah menerima
\end{abstract}

\section{PADJADJARAN Journal of Law Vol. 7 Number 3 Year 2020 [ISSN 2460-1543] [ISSN 2442-9325]}

Professor of Constitutional Law, Universitas Padjadjaran, Jalan Dipati Ukur Nomor 35 Bandung, S.H. (Universitas Padjadjaran), LL.M., Ph.D (University of Melbourne), susi.dwi.harijanti@unpad.ac.id.

Lecturer of the Department of Politics Studies, the Faculty of Social and Politics Studies, Universitas Padjadjaran, Jalan Raya Bandung-Sumedang No. 21 Kab. Sumedang, S.IP. (Universitas Padjadjaran), M.A. (Ohio University), firman.manan@unpad.ac.id.

*** Lecturer of the Department of Constitutional Law, the Faculty of Law, Universitas Padjadjaran, Jalan Dipati Ukur Nomor 35 Bandung, S.H. (Universitas Padjadjaran), M.H. (Universitas Indonesia), m.susanto@unpad.ac.id Student of Law Studies with Specialty on Constitutional Law, the Faculty of Law, Universitas Padjadjaran, Jalan Dipati Ukur Nomor 35 Bandung, ilham16002@mail.unpad.ac.id. 
kewarganegaraan lain karena kehendaknya sendiri. Syarat tersebut dapat menimbulkan kebingungan tentang siapa saja yang dapat dianggap sebagai warga negara sejak kelahiran dan bagaimana pembuktiannya. Tulisan ini bertujuan untuk menelusuri arti penting penetapan natural-born citizen sebagai syarat presiden dan implikasinya. Melalui pendekatan sosio-legal, artikel ini menyimpulkan arti penting syarat natural-born citizen adalah untuk menghilangkan diskriminasi rasial dari syarat presiden "orang Indonesia asli" dan untuk menjamin kesetiaan yang kuat dari presiden. Adapun implikasinya, pertama, setiap WNI yang lahir setelah berlakunya UU Kewarganegaraan tahun 2006, jika sejak kelahirannya telah berstatus WNI, tanpa melihat status etnis, disebut sebagai natural born citizen, termasuk di dalamnya berasal dari perkawinan campuran dan memiliki kewarganegaraan ganda terbatas sampai dengan usia 18 tahun. Sementara WNI yang lahir sebelum UU Kewarganegaraan tahun 2006, penentuan status WNI sejak kelahiran berdasarkan pengaturan UU 3 Tahun 1946 dan UU 62 Tahun 1958 termasuk perjanjianperjanjian yang diadakan Indonesia dengan Belanda dan Tiongkok. Kedua, natural born citizen secara mutatis mutandis seharusnya diberlakukan bagi syarat jabatan ketatanegaraan lainnya baik eksekutif, legislatif, maupun yudikatif, serta terhadap suami atau istri calon Presiden karena alasan kesetiaan.

Kata Kunci: kesetiaan, kewarganegaraan sejak kelahiran, syarat presiden.

\section{A. Introduction}

In 2018, Indonesia's people underwent a heated discussion on the requirements to become the President of Indonesia. A constitutional law expert, Yusril Ihza Mahendra, says that Basuki Tjahaja Purnama (Former Governor of DKI Jakarta) does not meet the requirements to become a presidential candidate. ${ }^{1}$ According to Yusril, Basuki does not fulfill one of the requirements according to Article 6 paragraph (1) of the Amendment of the 1945 Constitution, "A Presidential candidate and a Vice Presidential candidate has to be a natural-born Indonesian citizen...", because Basuki was born as Foreigner. Basuki's father, Tjoeng Kiem Nam (Indra Tjahaja Purnama), chose Chinese citizenship between Indonesia and China in the determination of citizenship in 1962. Since Basuki was born after the determination of citizenship in 1966, he is automatically not an Indonesian citizen. Yusril insists that Basuki started to become an Indonesian citizen in 1986 after his father, according to the Indonesian Citizenship Certificate (Surat Bukti Keterangan Kewarganegaraan Indonesia/SBKRI), naturalized and became an Indonesian citizen. ${ }^{2}$

Basuki's family denies Yusril's statement that their father was not an Indonesian citizen. According to Basuki's brother, Harry Basuki, his father has never been a

\footnotetext{
lil Askar Monza, "Yang Bikin Ahok Mustahil Jadi Calon Presiden Menurut Yusril Ihza", https://nasional.tempo.co/read/1075114/yang-bikin-ahok-mustahil-jadi-calon-presiden-menurut-yusrilihza/full\&view=ok, accessed on September, 2020.

2 Ihsan Dalimunthe, "Yusril Bersikukuh Ahok Lahir sebagai WNA dan Tak Bisa Nyapres", https://www.cnnindonesia.com/nasional/20180403214308-32-288039/yusril-berkukuh-ahok-lahir-sebagaiwna-dan-tak-bisa-nyapres, accessed on September, 2020.
} 
foreigner and is an Indonesian citizen, as evidenced by his birth certificate. He cannot be an Indonesian if his father is a foreigner. ${ }^{3}$ This case shows that someone's determination as a natural-born citizen is difficult and likely to result in the loss of Indonesian citizens' rights to run as a presidential and a vice-presidential candidate.

The constitutional issue from the above case is why the presidential candidate's requirement is a natural-born citizen? Is not that every citizen must be treated the same so that a presidential candidate's requirement is simply "citizenship" without an additional "natural-born" clause? Based on these problems, this article will examine the significances of "natural-born citizens" as a requirement for a candidate to be elected Indonesian President and its implications.

This study is different from other previous studies that have discussed presidential requirements or citizenship. For example, Susanto ${ }^{4}$ focuses on the requirements that a president must be a native Indonesian based on the preamended 1945 Constitution and its enactment after the amendment of the 1945 Constitution with a constitutional convention approach. Sitabuana ${ }^{5}$ focuses on dual citizenship. Nur'asia, Kasim, and Tavip ${ }^{6}$ focuses on children's dual citizenship status under 18 years of age.

This study employed a socio-legal study with an emphasis on the study of law in context. ${ }^{7}$ It is to understand the context and the significances of a natural-born citizen as a requirement and its implications. The socio-legal approach in this study does not leave on doctrinal studies. ${ }^{8}$ Therefore, the first part discusses doctrine/theory according to the topic under study, then contextualizing it on social issues, specifically looking at the history of the formulation of Article 6 of the 1945 Constitution both before and after the amendment. The discussion also covers further arrangements and relevant facts.

\section{B. Natural-Born Citizenship as a Requirement to be a President}

\section{Significances}

In the Indonesian constitutional law, the President is a state institution and has an important position. The 1945 Constitution makes the president the most regulated

3 Imam Hamdi, "Sebut Ahok Tak Bisa Jadi Presiden, Yusril Pertanyakan Surat Terbuka Harry Basuki", https://metro.tempo.co/read/1076035/sebut-ahok-tak-bisa-jadi-presiden-yusril-pertanyakan-surat-terbukaharry-basuki/full\&view=ok, accessed on September, 2020.

4 Mei Susanto, "Wacana Mengembalikan Syarat Presiden Orang Indonesia Asli Ditinjau dari Perspektif Ketatanegaraan”, Jurnal IImiah Kebijakan Hukum, Vol. 11, No. 2, 2017.

5 Tundjung Herning Sitabuana, "Indonesian Chinese Diaspora, Dual Citizenship and Indonesian Development", Constitutional Review, Vol. 1, No. 1, 2015.

$6 \quad$ Nur'asia, Aminuddin Kasim and Mohammad Tavip, "Status Kewarganegaraan Anak yang Lahir dari Perkawinan Beda Kewarganegaraan (Telaah Wacana Gloria Natapradja Hamel)", Tadulako Master Law Journal, Vol. 2, No. 1, 2019.

7 Reza Banakar, Normativity in Legal Sociology: Methodological Reflection in Late Modernity, Cham: Springer, 2015, pp. 48-49.

$8 \quad$ Reza Banakar and Max Travers, "Law, Sociology and Method," in Reza Banakar and Max Travers, ed., Theory and Method in Socio-Legal Research, Oxford \& Portland Oregon: Hart Publishing, 2005, p. 5. 
entity concerning authority, its relationship with other state institutions, ${ }^{9}$ the method of election and impeachment, ${ }^{10}$ up to the requirements to be a presidential candidate. ${ }^{11}$ Manan explains several presidential powers. The first is government administration power that includes administrative duties and powers in security and public order, government administration, public services, and public welfare administration. The second is powers in legislation that consist of forming laws, government regulations in lieu of laws, government regulations, and presidential regulations. The third is powers in the judicial sector, including granting clemency, amnesty, abolition, and rehabilitation. The fourth is power in foreign relations that consists of signing agreements, declaring war, and making peace with other states. $^{12}$

Manan argues the presidency is a crucial position and central to the Indonesian Government. The position requires experience, maturity, knowledge, insight, and various other pearls of wisdom. ${ }^{13}$ Therefore, there have to be some criteria for an individual holding the presidency, even though it can limit citizens' human rights. ${ }^{14}$

One crucial requirement is citizenship. According to Manan, it has become the argument that an important state position such as the President must be designated for a citizen of a reliable state concerned and, nevertheless, it is impossible to give the presidency to an alien/a foreigner. ${ }^{15}$ Foreigners are prohibited from occupying the position. Thus, Indonesia requires the presidential candidate to be a natural-born Indonesian citizen who has never received another citizenship of his/her own volition.

Based on micro ${ }^{16}$ comparison, ${ }^{17}$ there are 195 constitutions in the world have variations of citizenship requirements for important positions like president, prime minister (PM), the governor-general, king, or other designations. They can be classified as follows.

Table 1. Comparison of Citizenship Requirement for Leadership Position

\begin{tabular}{|l|l|l|}
\hline No. & Citizenship Requirement & \multicolumn{1}{|c|}{ State (Position Title) } \\
\hline 1. & Citizen/Nationality & $\begin{array}{l}\text { Albania (PM), Antigua and Barbuda (Governor } \\
\text { General and PM), Austria (President and Chancellor), }\end{array}$ \\
\hline
\end{tabular}

Bagir Manan, Lembaga Kepresidenan, Yogyakarta: FH UII Press, 2003, pp. 115-179.

lbid., pp. 75-113.

lbid., pp. 59-73.

lbid., pp. 115-179.

lbid., p. 67.

Bagir Manan, Hukum Kewarganegaraan, Yogyakarta: FH UII Press, 2009, p. 26.

Bagir Manan, Lembaga Kepresidenan, loc.cit, p. 61.

Micro comparison is a comparison of specific rules imposed on a particular society. See Ratno Lukito, Perbandingan Hukum: Perdebatan Teori dan Metode, Yogyakarta: Gadjah Mada University Press, 2016, pp. 3233.

17 Based on the search in June-September 2020 with reference to one hundred and nine fifty-five constitutions in all states (including Indonesia) compiled by the Constitute Project, "The World's Constitutions to Read, Search, and Compare", https://www.constituteproject.org/search?lang=en, accessed June-September 2020. 


\begin{tabular}{|c|c|c|}
\hline & & $\begin{array}{l}\text { Azerbaijan (President and PM), Andorra (Head of } \\
\text { Government), Bahamas (PM), Bahrain (PM), } \\
\text { Bangladesh (President and PM), Barbados (PM), } \\
\text { Belarus (PM), Belize (Governor General and PM), } \\
\text { Bolivia (President), Belgium (PM), Bulgaria (PM), } \\
\text { Canada (PM), Central African Republic (President), } \\
\text { Chile (President), People's Republic of China } \\
\text { (President), Cyprus (President), Czech (President and } \\
\text { PM), Denmark (PM), Djibouti (President), Dominica } \\
\text { (President and PM), Fiji (President and PM), Finland } \\
\text { (PM), Gabon (President), Georgia (President and } \\
\text { PM), Germany (President), Greece (PM), Grenada } \\
\text { (PM), Guinea (President), Hungary (President), } \\
\text { Iceland (President), India (President and PM), } \\
\text { Ireland (President and PM), Israel (President and } \\
\text { PM), Italy (President), Jamaica (PM), Jordan (PM), } \\
\text { Kiribati (President), Republic of Korea (President), } \\
\text { Kosovo (President and PM), Kyrgyzstan (President } \\
\text { and PM), Latvia (President and PM), Lebanon } \\
\text { (President and PM), Lesotho (PM), Liechtenstein } \\
\text { (Head of Government), Democratic Republic of } \\
\text { Congo (PM), Republic of North Macedonia } \\
\text { (President), Madagascar (President), Malaysia (PM), } \\
\text { Malta (President and PM), Marshall Islands } \\
\text { (President), Mauritius (President and PM), Moldova } \\
\text { (President), Monaco (Prince), Mongolia (PM), } \\
\text { Montenegro (President), Nauru (President), } \\
\text { Netherlands (PM), New Zealand (PM), Nicaragua } \\
\text { (President), Norway (PM), Pakistan (President and } \\
\text { PM), Palau (President), Palestine (PM), Poland } \\
\text { (President), Qatar (Emir), Romania (President and } \\
\text { PM), Russia (President), Saint Kitts and Nevis } \\
\text { Federation (Governor General), Saint Lucia } \\
\text { (Governor General), Saint Vincent and the } \\
\text { Grenadines (PM), Samoa (O le Ao o le Malo and } \\
\text { PM), Senegal (President),Serbia (President), } \\
\text { Seychelles (President), Sierra Leone (President), } \\
\text { Singapore (President and PM), Slovakia (President } \\
\text { and PM), Slovenia (President), Solomon Islands } \\
\text { (Governor General and PM), Somalia (President), } \\
\text { South Africa (President), Spain (Government } \\
\text { President), Sri Lanka (President and PM), Suriname } \\
\text { (President), Swaziland/Eswatini (PM), Sweden (King } \\
\text { and PM), Switzerland (President of the Federal } \\
\text { and PM), Tanzania (PM), Tonga (PM), Trinidad and }\end{array}$ \\
\hline
\end{tabular}




\begin{tabular}{|c|c|c|}
\hline & & $\begin{array}{l}\text { Tobago (President and PM), Turkey (President), } \\
\text { Tuvalu (Governor General and PM), Uganda (PM), } \\
\text { Ukraine (President), Union Arab Emirates } \\
\text { (President), United Kingdom (PM), Uzbekistan } \\
\text { (President), Vanuatu (PM), Venezuela (President), } \\
\text { Vietnam (President and PM), Yemen (PM). }\end{array}$ \\
\hline 2. & $\begin{array}{l}\text { Native-born } \\
\text { Citizen/Nationality }\end{array}$ & $\begin{array}{l}\text { Algeria (President), Argentina (President), Brazil } \\
\text { (President), Cape Verde (President), Finland } \\
\text { (President), Haiti (PM), Mali (President), Mauritania } \\
\text { (President). }\end{array}$ \\
\hline 3. & $\begin{array}{l}\text { Natural-born } \\
\text { Citizen/Nationality }\end{array}$ & $\begin{array}{l}\text { Australia (PM), Bhutan (PM), Bulgaria (President), } \\
\text { Indonesia (President), }{ }^{18} \text { Liberia (President), Mexico } \\
\text { (President), Paraguay (President), Philippines } \\
\text { (President), United States }{ }^{19} \text { (President), Uruguay } \\
\text { (President). }\end{array}$ \\
\hline 4. & Origin/Original Citizen & $\begin{array}{l}\text { Angola (President), Chad (President), Comoros } \\
\text { (President), Republic of Congo (President), Ivory } \\
\text { Coast (President), Dominican Republic (President), } \\
\text { Equatorial Guinea (President), Guatemala } \\
\text { (President), Guinea-Bissau (President), Haiti } \\
\text { (President), Iran (President), Kuwait (PM), Lithuania } \\
\text { (President), Democratic Republic of Congo } \\
\text { (President), Mozambique (President), Republic of } \\
\text { Niger (President), Oman (PM), Portugal (President), } \\
\text { Qatar (PM), Rwanda (President), Sao Tome and } \\
\text { Principe (President and PM), Timor-Leste } \\
\text { (President). }\end{array}$ \\
\hline 5. & $\begin{array}{l}\text { Citizen by Birth/At } \\
\text { Birth/Since Birth }\end{array}$ & $\begin{array}{l}\text { Albania (President), Belarus (President), Benin } \\
\text { (President), Botswana (President and PM), Burkina } \\
\text { Faso (President), Burundi (President and PM), } \\
\text { Cambodia (PM), Cameroon (President), Chad } \\
\text { (President), Colombia (President), Costa Rica } \\
\text { (President), Cuba (President and PM), Dominican } \\
\text { Republic (President), Ecuador (President), El } \\
\text { Salvador (President), Eritrea (President), Estonia } \\
\text { (President), Gambia (President), Ghana (President), } \\
\text { Guyana (President and PM), Honduras (President), } \\
\text { Iraq (President and PM), Kazakhstan (President), }\end{array}$ \\
\hline
\end{tabular}

18 The Constitute Project mentions the term "citizen since birth", not "natural-born citizen". This study puts Indonesia into the "natural-born citizen" group because during the drafting of the amendments to the 1945 Constitution, on presidential requirements, the discussion on "citizenship since birth" is always juxtaposed with the term "natural-born citizen". Read Mahkamah Konstitusi, Naskah Komprehensif Perubahan UndangUndang Dasar Negara Republik Indonesia Tahun 1945, Latar Belakang, Proses, dan Hasil Pembahasan, 1999 2002: Buku IV Kekuasaan Pemerintahan Negara, Jakarta: Sekretariat Jenderal Mahkamah Konstitusi, 2010, p. 132.

19 In addition to natural-born citizen, the US Constitution also has a clause Citizen at the time of the Adoption of this Constitution, only valid once at the time of American independence. 


\begin{tabular}{|c|c|c|}
\hline & & $\begin{array}{l}\text { Kenya (President), Malawi (President), Federated } \\
\text { States of Micronesia (President), Namibia } \\
\text { (President), Nigeria (President), Panama (President), } \\
\text { Peru (President and Cabinet President), South Sudan } \\
\text { (President), Sudan (Chairman of the Sovereign } \\
\text { Council and PM), Syria (President), Tanzania } \\
\text { (President), Thailand (PM), Togo (President), Tunisia } \\
\text { (President), Uganda (President), Zambia (President), } \\
\text { Zimbabwe (President). }\end{array}$ \\
\hline 6. & By Descent/By Parentage & $\begin{array}{l}\text { Afghanistan (President), Algeria (President), } \\
\text { Argentina (President), Botswana (President and PM), } \\
\text { Chad (President), Comoros (President), Egypt } \\
\text { (President and PM), El Salvador (President), Gambia } \\
\text { (President), Greece (President), Guinea-Bissau } \\
\text { (President), Guyana (President and PM), Iraq } \\
\text { (President and PM), Malawi (President), Maldives } \\
\text { (President), Mexico (President), Myanmar } \\
\text { (President), Namibia (President), Nepal (President } \\
\text { and PM), Oman (Sultan), Saint Kitts and Nevis } \\
\text { Federation (PM), Sao Tome and Principe (President } \\
\text { and PM), Syria (President), Yemen (President), } \\
\text { Zambia (President), Zimbabwe (President). }\end{array}$ \\
\hline 7. & $\begin{array}{l}\text { Born in the state territory/in } \\
\text { the electorate }\end{array}$ & $\begin{array}{l}\text { Argentina (President), Comoros (President), } \\
\text { Myanmar (President), Papua New Guinea (Governor- } \\
\text { General and PM), Saint Kitts and Nevis Federation } \\
\text { (PM), Saint Lucia (PM), Turkmenistan (President). }\end{array}$ \\
\hline 8. & Indigenous Citizen & Mongolia (President), and Vanuatu (President). \\
\hline 9. & $\begin{array}{l}\text { Otherwise than by } \\
\text { naturalization }\end{array}$ & Gabon (President), and Sierra Leone (President). \\
\hline 10. & Citizen in few years & $\begin{array}{l}\text { Armenia (President), Australia (PM), Benin } \\
\text { (President), Greece (President). }\end{array}$ \\
\hline 11. & Have dual citizenship & Kiribati (President). \\
\hline 12. & Based on ethnicity/race & $\begin{array}{l}\text { Bosnia and Herzegovina (Member of the } \\
\text { Presidency), and Cyprus (President and Vice } \\
\text { President). }\end{array}$ \\
\hline 13. & $\begin{array}{l}\text { Has no commitments } \\
\text { towards other States/Never } \\
\text { betrayed the country }\end{array}$ & $\begin{array}{l}\text { Azerbaijan (President and PM), Antigua and Barbuda } \\
\text { (PM), Australia (PM), Bahamas (PM), Bangladesh } \\
\text { (President and PM), Barbados (PM), Belize (PM), } \\
\text { Bhutan (PM), Botswana (President and PM), } \\
\text { Dominica (President and PM), Gabon (President), } \\
\text { Ghana (President), Grenada (PM), Guyana (President }\end{array}$ \\
\hline
\end{tabular}




\begin{tabular}{|c|c|c|}
\hline & & $\begin{array}{l}\text { and PM), India (President and PM), Indonesia } \\
\text { (President), Jamaica (PM), Kenya (President), Kiribati } \\
\text { (President), Lesotho (PM), Lithuania (President and } \\
\text { PM), Malawi (President), Malaysia (PM), Malta (PM), } \\
\text { Mauritius (PM), Myanmar (President), Nigeria } \\
\text { (President), Federation of Saint Kitts and Nevis (PM), } \\
\text { Saint Vincent and the Grenadines (PM), Singapore } \\
\text { (President and PM), Solomon Islands (Governor } \\
\text { General and PM), (President and PM), Tuvalu } \\
\text { (Governor General and PM). }\end{array}$ \\
\hline 14. & $\begin{array}{l}\text { Does not have dual } \\
\text { citizenship/Does not have } \\
\text { any other citizenship }\end{array}$ & $\begin{array}{l}\text { Azerbaijan (President), Bulgaria (President and PM), } \\
\text { Chad (President), Colombia (President), Cuba } \\
\text { (President and PM), Equatorial Guinea (President), } \\
\text { Fiji (PM), Gambia (President), Georgia (President } \\
\text { and PM), Haiti (President), India (President and PM), } \\
\text { Israel (PM), Kenya (President), Kyrgyzstan (President } \\
\text { and PM), Latvia (President), Malaysia (PM), Maldives } \\
\text { (President), Malta (PM), Mozambique (President), } \\
\text { Myanmar (President), Nigeria (President), Pakistan } \\
\text { (President and PM), Rwanda (President), Sao Tome } \\
\text { and Principe (President and PM), Singapore } \\
\text { (President and PM), Sri Lanka (President and PM), } \\
\text { Sudan (Chair of the Sovereign Assembly and PM), } \\
\text { Syria (President and PM), Tanzania (President and } \\
\text { PM), Venezuela (President), Zambia (President). }\end{array}$ \\
\hline 15. & $\begin{array}{l}\text { Not a citizen of another } \\
\text { country by } \\
\text { volunteering/Never leave his } \\
\text { citizenship }\end{array}$ & $\begin{array}{l}\text { Bahamas (PM), Haiti (President and PM), Indonesia } \\
\text { (President). }\end{array}$ \\
\hline 16. & $\begin{array}{l}\text { Obtaining another citizenship } \\
\text { voluntary or not voluntarily } \\
\text { and renounced that other } \\
\text { citizenship }\end{array}$ & $\begin{array}{l}\text { Bangladesh (President and PM), Dominican Republic } \\
\text { (President), Nicaragua (President), Tunisia } \\
\text { (President). }\end{array}$ \\
\hline 17. & $\begin{array}{l}\text { Not married to a citizen of } \\
\text { another country/must be } \\
\text { married to someone who has } \\
\text { the same citizenship }\end{array}$ & $\begin{array}{l}\text { Algeria (President), Bhutan (King and PM), Egypt } \\
\text { (President and PM), Myanmar (President), Syria } \\
\text { (President), Yemen (President). }\end{array}$ \\
\hline 18. & $\begin{array}{l}\text { Does not specify } \\
\text { nationality/citizenship }\end{array}$ & $\begin{array}{l}\text { Brunei Darussalam (Sultan/Yang di-Pertuan), Algeria } \\
\text { (PM), Armenia (PM), Australia (Governor General), } \\
\text { Bahamas (Governor General), Bahrain (King), } \\
\text { Barbados (Governor General), Belgium (King), Benin } \\
\text { (PM), Bosnia and Herzegovina (Chairman of the } \\
\text { Council of Ministers), Burkina Faso (PM), Cambodia }\end{array}$ \\
\hline
\end{tabular}




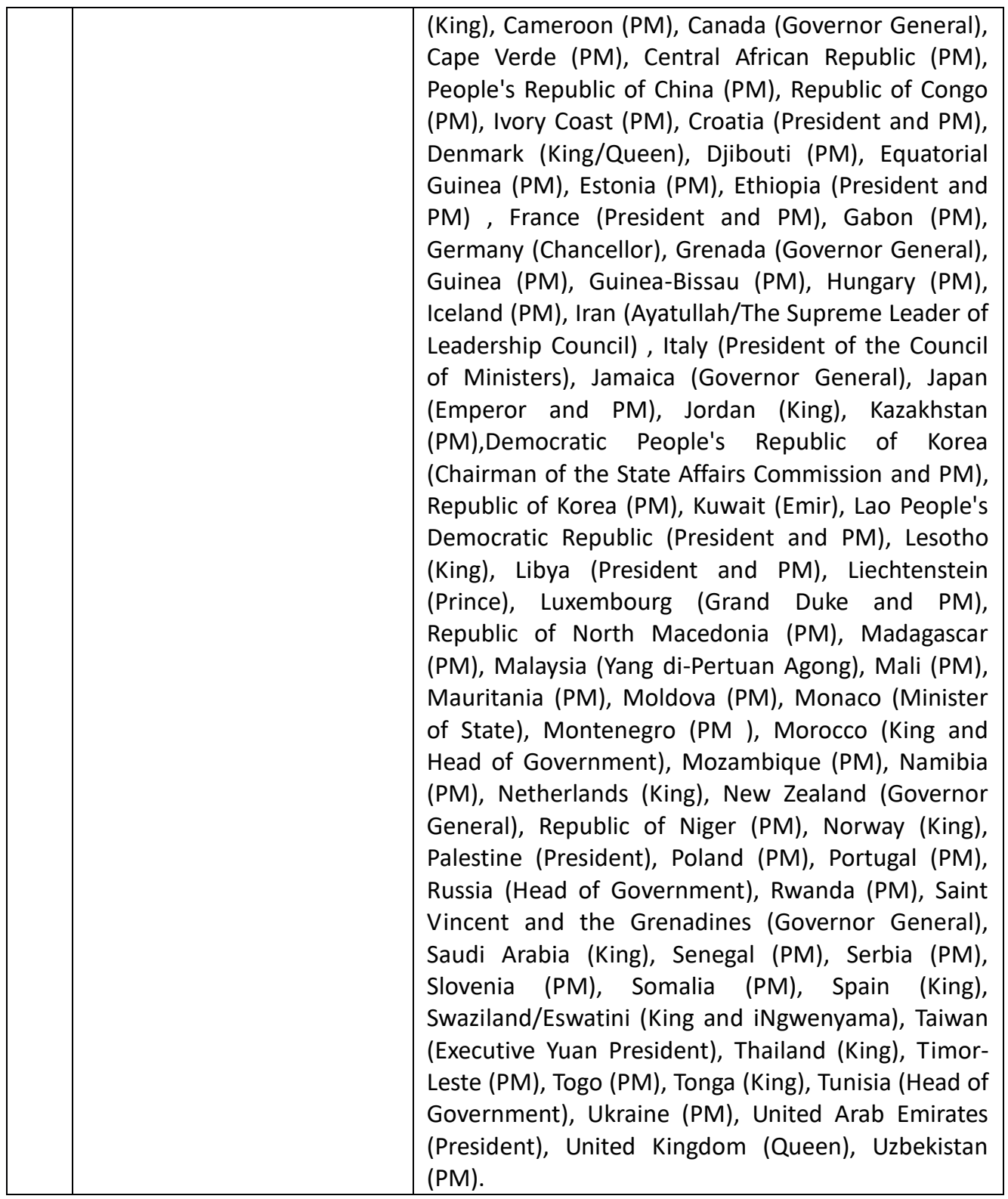

The table provides some important information. First, the citizenship requirement is the main requirement for the presidency. Only six states do not include citizenship as a condition for president in their constitution, namely Palestine, Libya, Laos, France, Croatia, and Ethiopia. However, France still stipulates the requirements for 
French citizenship in law. ${ }^{20}$ The rest, either in a presidential, parliamentary, or mixed systems, always include the presidency's citizenship requirements.

On the other hand, positions that often do not require citizenship (but many states have decided otherwise) are PM, king, queen, emperor, sultan, and governorgeneral. For a king or other equivalent royal term, this is, of course, not necessary because a king must be a citizen; even such right is given exclusively to the king's descendants. Then, the governor general's position, which is generally found in the British Commonwealth states, is held mostly by citizens of each state. Previously, British people who represent the queen filled the position. ${ }^{21}$

Second, there are various terms of citizenship as a requirement for the head of state or the head of government, for example, the term citizen/nationality, naturalborn citizen, original/indigenous citizen, citizen-based on certain descent/race, citizen-based on place of birth, and other unspecific citizenship requirements. There are also various terms for a natural-born citizen: native-born citizen, natural-born citizen, citizen by birth/at birth/since birth.

Third, only one state allows the president to have dual citizenship, namely Kiribati. Some other states require citizens after several years and allow a naturalized citizen to hold the head of state and the head of government positions, such as Armenia, Australia, Benin, and Greece. There is also the requirement for not having a commitment to other states or never committing treason. Even there is a requirement not to marry a citizen of another state in the sense that the husband/wife must be a citizen of the same state.

The essential of the citizenship requirement as the general requirement for a state-leadership position is nothing but the philosophy of citizenship/nationality. It is based on the doctrine of perpetual allegiance. ${ }^{22}$ This doctrine is considered to have originated from the feudal era. However, in globalization, it is possible to combine it with mixed marriage or other forms related to dual citizenship. Overall, the comparison shows that the concept of perpetual allegiance is still relevant for state-leadership positions, either head of state or head of government.

For example, in PM's position, many states do not require citizenship or only require citizenship without prohibiting non-citizenship, enabling people with dual citizenship to obtain the office. ${ }^{23}$ However, even if a person with dual citizenship

20 See French Embassy in the United Kingdom, "Five Things You Need to Know about the French Presidential Election", https://uk.ambafrance.org/Five-things-you-need-to-know-about-the-French-presidential-election, accessed on September 2020.

21 CBC News, "The Role of Canada's Governor General", https://www.cbc.ca/news/canada/the-role-of-canada-sgovernor-general-1.907373, accessed on September 2020.

22 Paul Weis, Nationality and Statelessness in International Law, Netherland: Sijthoff \& Noordhoff International Publisher, 1979, p. 30.

23 Henry Belot, "Dual Citizens around the World: These Countries Don't Have the Same Problem We Do", https://www.abc.net.au/news/2017-11-07/dual-citizenship-around-the-world/9126438, accessed on September 2020. Also read: Andrew Henderson, "8 Countries Where You Can Become President With a Second Passport", https://nomadcapitalist.com/2017/12/01/countries-president-with-second-passport/, accessed on September 2020. 
runs for office, the state's people criticize dual citizenship tenure. Mostly the people fear a conflict of interest and partial allegiance. In most cases, candidates renounce the other citizenship. For example, Boris Johnson, the PM of the United Kingdom, once held dual citizenships of the United Kingdom and the United States and Andrew Scheer, leader of the Canadian Conservative Party and Justin Trudeau's main competitor in the race for the PM's seat, has dual Canadian and the United States citizenship. ${ }^{24}$ Thus, it is generally difficult to find a state or society that allows, either in writing or in practice, head of state and head of government to be occupied by someone who has dual citizenships (except Kiribati), let alone foreign citizens.

The link between a person's single citizenship and the state in terms of allegiance is still considered necessary, not only related to legal status and rights but also shows political activity and a form of collective identity and feeling. ${ }^{25}$ Vogel $^{26}$ and Meehan ${ }^{27}$ state that citizenship is related to a person's status as a full member of a specific political community. Therefore, the single-citizenship requirement is the main requirement for an important national position. This is in line with the general opinion of citizenship that, according to Weis, shows the specific relationship between an individual and a state that confers joint rights and obligations. Citizenship status also distinguishes the relationship between foreigners and the state. ${ }^{28}$ The Code of Private International Law, signed in Havana 1928 (Bustamante Code), defines nationality ${ }^{29}$ as "the national character of a person in his connection with a nation, being one of its members... (Article 248)"; and allegiance (loyalty) as "the obligation of fidelity and obedience which a person owes to the nation of which he is a member or to its sovereign (Article 261) ". ${ }^{30}$

Since citizenship speaks of a person's allegiance to her/his state, it is only natural that many states limit only those with single citizenship who can hold important positions like the head of state and the head of government. Because it is considered to interfere with one's allegiance, dual citizenship has been seen as "the greatest evil of present international life". ${ }^{31}$ Therefore, it can be seen in the comparison table above that so many states do not only require citizenship but also forbid candidates to have commitments to other states, let alone treason.

24 BBC News, "Could an American be Canada's Next Prime Minister ?, https://www.bbc.com/news/world-uscanada-49938384, accessed on September 2020.

25 See Kim Rubenstein and Daniel Adler, International Citizenship: The Future of Nationality in a Globalized World in Susi Dwi Harijanti, Rahayu Prasetianingsih, and Bilal Dewansyah, "Politik Hukum Kewarganegaraan Indonesia", Research Report of the Faculty of Law, Padjadjaran University, Bandung, 2007, p. 28.

26 Ursula Vogel and Michael Moran (eds), The Frontiers of Citizenship, London: MacMillan, 1991, p. 62.

$27 \quad$ Ibid., p. 126.

28 Paul Weis, op.cit, p. 29.

29 According to Paul Weis, "Nationality" is used more frequently in international law, while "citizenship" is used more frequently in national legal frameworks, in Paul Weis, Ibid., pp. 4-5.

Ibid., p. 32.

31 Gouw Jade Siong, Interpretation of the Citizenship Law of the Republic of Indonesia, Djakarta: Keng Po, 1960, p. 2. 
Furthermore, although single citizenship is considered a proof of allegiance, several states, such as the United States, Uruguay, including Indonesia, require the president a natural-born citizen.

Referring to the oldest constitution that applies the requirement in the United States Constitution, there is no in-depth discussion or debate regarding the "natural-born citizen" clause at the constitution-forming convention. The origins of the clause are believed to be influenced by a letter from John Jay (secretary of foreign affairs) sent to George Washington (Head of the 1787 Constitutional Convention who later became the first president of the United States) concerning the existence of very wealthy European aristocrats and nobles who were extremely wealthy. They might come to the United States, gain citizenship, "buy" friends in numbers and plan their way to the presidency without long-standing allegiance to the United States. Therefore, Jay stated, "permit me to hint, whether it would not be wise \& seasonable to provide a strong check to the admission of foreigners into the administration of our national Government; and to declare expressly that the Command in chief of the American army shall not be given to, nor devolve on, any but a natural-born citizen. ${ }^{432}$

This concern is reasonable to consider because, at that time, there was an incident in Europe, to be precise, in Poland, which had an elective monarchy system, where outside powers succeeded in occupying the position of the king in that country. ${ }^{33}$ Furthermore, there were rumors during the convention that Bishop of Osnabrück, the second son of King George III, would be invited to America to form an empire and become the King of America. ${ }^{34}$ There is also another rumor that Nathaniel Gorham, President of Congress at the time, when America was still a confederation, and a convention delegate from New Hampshire, had approached Prince Henry of Prussia to become the King of America. ${ }^{35}$

Due to concerns about foreign influence, in addition to the reluctance of the constitution drafters to form a royal government, the founding fathers made "shields" to prevent foreigners from becoming president. ${ }^{36}$ However, the academics add that Jay intended to ensure sufficient allegiance to America that he emphasized the word "born". ${ }^{37}$ It means that the people who are American citizens "since their birth" can develop the allegiance and respect for America, who are inherited,

32 Jack Maskell, "Qualification for President and the" Natural Born "Citizenship Eligibility Requirement", Congressional Research Service Report for Congress, Washington DC, 2011, p. 6.

33 Ibid., pp. 6-7. Also read Richard Skinner, "The Constitution's" Natural-Born "Defect", https://www.vox.com/mischiefs-of-faction/2019/4/15/18308338/natural-born-citizen-us-president, accessed on September 2020.

34 Max Farrand, The Framing of the Constitution of The United States, New Haven: Yale University Press, 1913, p. 173.

35 Jack Maskell, loc.cit., p. 7.

36 Lawrence Friedman, "An Idea Whose Time Has Come - The Curious History, Uncertain Effect, and Need for Amendment of the" Natural Born Citizen "Requirement for the Presidency", Saint Louis University Law Journal, Vol. 52, No. 1, 2007, p. 142.

37 Ibid. 
instilled, and taught by their parents or because of an attachment to their homeland to have lifelong allegiance America. ${ }^{38}$ This is certainly a difference with naturalized citizen because they do not give allegiance from the beginning of their life. Mason says a naturalized citizen might carry attachments to other states or even ideas from a different state government, affecting the nation. ${ }^{39}$

In Indonesia, the requirement of "natural-born citizen" follows the Third Amendment to the 1945 Constitution. It changed Article 6 paragraph (1) reads " $A$ presidential candidate and a vice presidential candidate has to be a natural-born Indonesian citizen, who has never received another citizenship of his own volition, who has never betrayed the country, and who is mentally and physically capable of carrying out his duties as president or vice president". There are two significances behind the change in citizenship requirements, namely the desire "to eliminate discrimination and "to ensure strong allegiance to Indonesia".

Discrimination arises from the word "native" creates the impression of distinguishing native Indonesians from non-native Indonesians. The 1945 Constitution affirms that every citizen has the same position before the law and government (Article 27 paragraph [1] and Article 28D paragraph [3]) and has the right to be free from discriminatory treatment (Article 28I paragraph [2]). However, this discriminatory understanding cannot be separated from the meaning attached to "native Indonesian", namely inlanders or bumiputra based on Article 131 of Indische Staatsregeling (IS). ${ }^{40}$ This is difficult to avoid considering Article 26 paragraph (1) of the 1945 Constitution states that "those who become citizens are the native Indonesian peoples and people of other nations..." The Explanation of the pre-amended 1945 Constitution states, "people from other nations such as Dutch, Chinese, and Arab descents residing in Indonesia..." Of its own accord, "native Indonesian" refers to bumiputra. Muhammad Yamin reinforced the definition. He mentioned that Soepomo, a drafter of the 1945 Constitution at The Investigating Committee for Preparatory Work for Independence (BPUPKI -Badan Penyelidik Usaha-usaha Persiapan Kemerdekaan) has equated "native Indonesian" with bumiputra. $^{41}$

The requirement did not intend to discriminate, considering that the BPUPKI consisted of 4 Chinese descents, 1 Arab descent, and 1 Dutch descent. However, during the formulation, some group representatives, namely Liem Koen Hian, Baswedan, and Dahler, objected to the clause "native". They wanted the clause to be "Indonesian nation". However, Soepomo believed that there would be international legal problems if immigrant groups immediately obtained Indonesian citizenship status, considering that the groups still had foreign national status,

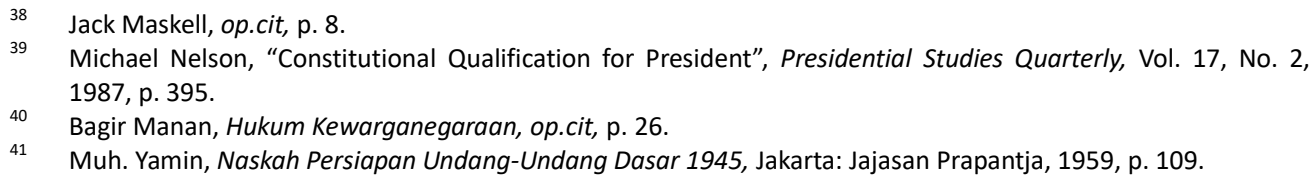


according to the Onderdaan Nederlandsch. ${ }^{42}$ Soepomo emphasizes a need for "a group with a clearer status" to automatically become citizens, while other groups are regulated by law. ${ }^{43}$ The clause "native" was later agreed upon, although there were some objections. As a result, Liem Koen Hian resigned from the BPUPKI. ${ }^{44}$

Indeed, initially, the clause was not intended to create discrimination. Moreover, Manan says that discrimination does not lie in the "native" or "nonnative". ${ }^{45}$ However, in practice, there are differences in treatment and opportunities due to citizenship backgrounds. Consequently, the interpretation of the clause "native", allegedly referring to "discrimination", was later discussed in the amendments to the 1945 Constitution from 1999-2001. For example, Tunggu Sirait from the National Love Democracy Party Faction (Fraksi Partai Demokrasi Kasih Bangsa) proposed that the president should be a natural-born Indonesian citizen to prevent discrimination from the word "native". ${ }^{46}$ Suryadarma Ali, from the United Development Party Faction (Fraksi Partai Persatuan Pembangunan) made a similar statement that the phrase native Indonesians needed to be changed to avoid racial discrimination in the citizenship's legal status. He insisted that the phrase "orang Indonesia asli" (literally means "native/indigenous Indonesian people") should not be changed with "warganegara Indonesia asli" (native Indonesian citizen). He proposed to replace it with another term that is more appropriate so that Indonesia can avoid using terms that can be misused and eventually lead to racial discrimination again. ${ }^{47}$ Sahetapy from the Indonesian Democratic Party of Struggle Faction (Fraksi Partai Demokrasi Indonesia Perjuangan) said that the "native" clause could sow the seeds of Nazism. ${ }^{48}$ Patrialis Akbar from the Reform Faction (Fraksi Reformasi) protested by calling it untrue that the concept of native citizens "smells of Nazism". ${ }^{49}$ Amien Rais mediated the debate. He reminded Slamet Effendy Yusuf from the Golkar Party Faction (Fraksi Partai Golongan Karya) that almost no faction wanted the "President is a native Indonesian" which was felt to be discriminatory. ${ }^{50}$

In addition to the desire to eliminate racial discrimination, the framers of the Amendment also did not want the presidential to be an only Indonesian citizen. Their concerns were almost similar to be the same as that of the founding fathers of the United States. For example, Nur Muhammad Iskandar from the National

\footnotetext{
42 AB. Kusuma, Lahirnya Undang-Undang Dasar, Jakarta: Badan Penerbit Fakultas Hukum Universitas Indonesia, 2009, p. 399.

48 Mahkamah Konstitusi, Naskah Komprehensif Perubahan Undang-Undang Dasar Negara Republik Indonesia Tahun 1945, Latar Belakang, Proses, dan Hasil Pembahasan, 1999-2002: Buku IV Kekuasaan Pemerintahan Negara, op.cit, p. 125.

49 Ibid., pp. 127-128.

50 Ibid.
} 
Awakening Party Faction (Fraksi Partai Kebangkitan Bangsa) says that the requirement to be only a citizen is too loose a requirement. He says that there may be foreigners who become citizens, seeking sympathy for making them president and messing up Indonesia. ${ }^{51}$ Slamet from Golkar also conveyed a similar sentiment regarding concerns about the possibility of wealthy foreigners becoming citizens and becoming president of Indonesia. ${ }^{52}$ Therefore, two alternatives emerged: native Indonesian citizen or natural-born Indonesian citizen.

The two alternatives indicate that the framers of the amendment intend that a naturalized citizen cannot be elected president. This is closely related to why the allegiance of naturalized citizen is considered not strong enough for Indonesia. ${ }^{53}$ In the end, choosing the phrase "natural-born Indonesian citizen" considering that the word "native" or "indigenous" can lead to discrimination issues. ${ }^{54}$ Thus, a naturalborn citizen's requirement is a middle way to accommodate two significances for the presidential requirement: eliminating discrimination and ensuring sufficient allegiance to Indonesia.

\section{Implications}

\section{a. Implications of the Natural-Born Citizen Requirement and Limited Dual Citizenship}

The implications of a natural-born citizen's requirement will vary among states, depending on each state's citizenship laws. In the United States, ${ }^{55}$ the natural-born citizen is valid for those born in the United States. It is regardless of the citizenship of the parents (based on the jus soli principle) ${ }^{56}$ according to English common law tradition ${ }^{57}$ or those born to both parents and one of whom is a citizen of the United States (based on the principle of jus sanguinis), which is based on the Naturalization Act of $1790 .^{58}$

\footnotetext{
Ibid., p. 107.
}

Ibid., p. 97.

53 Mahkamah Konstitusi, Naskah Komprehensif Perubahan Undang-Undang Dasar Negara Republik Indonesia Tahun 1945, Latar Belakang, Proses, dan Hasil Pembahasan, 1999-2002: Buku IV Kekuasaan Pemerintahan Negara, op.cit, p. 161.

54 Mahkamah Konstitusi, Naskah Komprehensif Perubahan Undang-Undang Dasar Negara Republik Indonesia Tahun 1945, Latar Belakang, Proses, dan Hasil Pembahasan, 1999-2002: Buku VIII Warga Negara dan Penduduk, Hak Asasi Manusia dan Agama, loc.cit, p. 599.

55 The American Supreme Court, in addition to using the term natural born citizen, also uses the terms citizen by birth/at birth and native-born/native citizen. It should be noted that the US Supreme Court defines nativeborn/native citizen more narrowly than natural-born citizen or citizen by/at birth, which is only citizens born in America, and does not include those born outside the horror of American citizens' parents, which is called citizen by/at birth. See the Decision of the American Supreme Court in the case of United States v. Wong Kim Ark (1898), Schneider v. Rusk (1964), Maclntosh v. United States (1930), and United States v. Schwimmer (1929). In Jack Maskell, op.cit, pp. 2-3, 30, 33.

56 See United States Supreme Court Decision in the case of United States v. Wong Kim Ark (1898), in Jack Maskell, op.cit, p. 2.

57 The clause or the term "natural-born citizen" itself is rooted in the common law citizenship law in the UK (which applies jus soli or citizenship based on place of birth), although it is not used in the terms of the head 
In Indonesia, finding out natural-born citizen must refer to the 1945 Constitution and the 2006 Citizenship Law. Article 26 paragraph (1) of the 1945 Constitution states that Citizens are native Indonesian peoples and people of other nations legalized by law as citizens. This article has not been changed from the preamended 1945 Constitution. It is still a problem because, in addition to not explaining who a natural-born citizen is, it also indirectly leaves discrimination.

The Explanation of Article 2 of Law number 12 of 2006 on Citizenship explains that the requirement "natural born Indonesian citizen, who has never received another citizenship of his own volition" means "native Indonesian peoples" as contained in Article 26 of the 1945 Constitution. Although it is not following the meaning of "native Indonesia" from the 1945 Constitution pre-amendment, it can be concluded that it is follows the wishes of the Framers of the Amendment of the 1945 Constitution to change the paradigm of "native". 59 Unfortunately, the 2006 Law does not explicitly explain a natural-born citizen's qualifications because it only mentions Indonesian citizen in general.

It is important to pay attention to Article 4 paragraph a of the 2006 Citizenship Law. Indonesian citizens are people who are declared as Indonesian citizens based on laws or agreements in effect before the 2006 Citizenship Law. This means that the meaning of natural-born citizens does not only refer to the 2006 Citizenship Law. It refers to the meaning of any law or agreement related to citizenship since independence, ${ }^{60}$ depending on when was someone born. Identification up to the citizenship law since independence is important because there are still many citizens who were even born before Indonesian independence in 1945 . It can become a problem if they are proposed to be a presidential or vice-presidential candidate because their status can be questioned. In the case of Vice President Ma'ruf Amin who was born in $1943,{ }^{61}$ it is not an issue because Amin must be included in the natural-born Indonesian citizen, considering that he was not born from a mixed marriage and did not belong to the European or Foreign East by origin.

According to Manan, the clause "natural-born citizen" in the 2006 Citizenship Law refers to people that are regulated in Article 4 paragraph b, c, d, e, f, g, and I (based on the jus sanguinis principle) and Article 4 paragraph $\mathrm{i}$ and $\mathrm{j}$ (based on the jus soli principle). They are, among others, people who are (1) born from a legal marriage of Indonesian father and mother; (2) born from a legal marriage of an Indonesian citizen father and a foreign citizen mother; (3) born from a legal marriage of a foreign citizen father and an Indonesian citizen mother; (4) born from a legal marriage of Indonesian citizens but the father does not have citizenship, or

\footnotetext{
59 Mahkamah Konstitusi, Naskah Komprehensif Perubahan Undang-Undang Dasar Negara Republik Indonesia Tahun 1945, Latar Belakang, Proses, dan Hasil Pembahasan, 1999-2002: Buku VIII Warga Negara dan Penduduk, Hak Asasi Manusia dan Agama, op.cit, p. 114.

60 Bagir Manan, Hukum Kewarganegaraan, op.cit, p. 67.

61 Tirto.id, "Ma'ruf Amin", https://tirto.id/m/maruf-amin-bM, accessed on September, 2020.
} 
the law of the country of origin regulates that the father does not grant citizenship to the child; (5) born within a period of $\mathbf{3 0 0}$ (three hundred) days after their father dies after a legal marriage and the father is an Indonesian citizen; (6) born from extramarital relationship of an Indonesian citizen (based on jus sanguinis); and (7) born in the territory of the Republic of Indonesia in the condition that the citizenship status of father and mother was not clear; (8) new born children who are found in the territory of the Republic of Indonesia as long as their father and mother are not known; and (9) a child born in the territory of the Republic of Indonesia and the father and the mother are stateless, or where their whereabouts are unknown; born outside the territory of the Republic of Indonesia from an Indonesian father and mother who due to the provisions of the state where the child was born grants citizenship to the child concerned (based on jus soli). ${ }^{62}$

On the other hand, there are exception for children listed in Article 4 paragraph $\mathrm{h}$ and $\mathrm{m}$ of the Law. Article 4 paragraph $\mathrm{h}$ covers children are born out of legal marriages from foreign nationals, do not get their citizenship since birth and only get Indonesian citizenship when/since their father, an Indonesian citizen, recognizes them before the age of 18 . Article 4 paragraph $\mathrm{m}$ refers to father and mother who are naturalized or becomes Indonesian citizens but died before taking an oath or declaring a pledge of allegiance even though their naturalization request had been granted, whom father and mother becomes citizens, and the naturalization request has been granted and not before the child was born. ${ }^{63}$

Furthermore, based on the Law number 62 of 1958 on Citizenship, which adheres to the limited jus sanguinis and jus soli principles, ${ }^{64}$ someone is considered a natural-born citizen according to Article 1 letters b, c, d, e (based on jus sanguinis) and letters $\mathrm{f}, \mathrm{g}, \mathrm{h}$, and $\mathrm{i}$ (based on jus soli). They are (1) a person who at birth has legal family relationship with his father, who is a citizen of the Republic of Indonesia; (2) a person who at born within 300 days after his father's death, if the father at the time of death is a citizen of the Republic of Indonesia; (3) a person whose mother was a citizen of the Republic of Indonesia, if at that time he did not have a family law relationship with his father; (4) a person whose mother is a citizen of the Republic of Indonesia, if, at the time of birth, the father does not have citizenship, or as long as the citizenship of the father is not known (based on jus sanguinis); (5) a person who was born within the territory of the Republic of Indonesia as long as both parents are unknown; (6) a person who is found in the territory of the Republic of Indonesia as long as the parents are unknown; (7) a person who was born within the territory of the Republic of Indonesia and both parents do not have citizenship or as long as the citizenship of both parents is unknown; and (8) a person born within the territory of the Republic of Indonesia

Bagir Manan, Hukum Kewarganegaraan, op.cit, p. 61.

Ibid.

See Sudargo Gautama, Warga Negara dan Orang Asing, Bandung: Alumni, 1987, p. 120. 
who at birth does not have the citizenship of his father or mother and as long as he does not have the citizenship of his father or mother (based on jus soli).

Then based on the Law Number 3 of 1946 on Resident and Citizen, ${ }^{65}$ naturalborn citizen includes people who are mentioned in Article 1 paragraph a, $d, e$, and $f$ based on jus sanguinis; letters $h$ and $i$ based on jus soli; and letter $b$ based on the combination of jus sanguinis and jus soli. They are (1) persons who are native to the territory of the State of Indonesia; (2) persons who are not included in the aforementioned group but is a descendant of a person from that group, who is born and has a domicile and residence in the territory of the State of Indonesia, and a person not included in the group, who is born and has a domicile and residence for as long as at least 5 consecutive years within the territory of the State of Indonesia, who is 21 years old, or has been married, unless he/she expresses objection to becoming an Indonesian citizen because he/she is a citizen of another country; (3) persons who are legitimate, legalized, or recognized in a lawful manner by a father having Indonesian citizenship at the time of birth; (4) persons who are born within 300 days after the father, who has Indonesian citizenship, passes away; (5) persons whose mother is recognized only in a lawful manner, and at the time of birth the mother has Indonesian citizenship (based on jus sanguinis); (6) children born in the territory of the State of Indonesia, who are not recognized by their father or mother by lawful means; and (7) persons who were born in the territory of the State of Indonesia and have parents with unknown existence or citizenship (based on jus soli).

Furthermore, concerning the requirement of "never accepting another citizenship" in Article 6 paragraph (1) of the 1945 Constitution, a person may be deemed not to fulfill this clause if he chooses another citizenship. For example, if an Indonesian citizen has been naturalized in a foreign country and a woman renounces her Indonesian citizenship, she follows her husband's citizenship, who is not an Indonesian citizen. Manan is also of the opinion that it includes a child whose parents renounce Indonesian citizenship so that the child becomes a citizen of another country. When she/he is an adult accepts naturalization and becomes an Indonesian citizen again, she/he will not be considered a natural-born citizen, but because of naturalization. In such a case, a person will be deemed to remain a natural-born citizen if there is a general state decision, such as a statutory provision or a government policy that stipulates that any person who loses citizenship without their will is deemed to have never lost citizenship upon regaining their Indonesian citizenship. Manan says that this could happen, for example, for Indonesian citizens who go abroad without sufficient immigration documents to prove that they are Indonesian citizens. ${ }^{66}$

\footnotetext{
65 Gouw Giok Siong in Kurniatmanto Sutoprawiro, Hukum Kewarganegaraan dan Keimigrasian Indonesia, Jakarta: Gramedia, 1994, p. 28.

66 Bagir Manan, Hukum Kewarganegaraan, op.cit, pp. 62-63.
} 
Based on the above description, there are some implications to be concluded. First, every Indonesian citizen born after the establishment of the 2006 Citizenship Law, who has obtained an Indonesian citizen's status since birth, can be considered a natural-born citizen regardless of certain ethnicity/descent. It includes people from mixed marriages having limited dual citizenship up to the age of 18. Second, every Indonesian citizen born before the 2006 Citizenship Law is subject to the previously applicable regulations, Law number 3 of 1946 and Law number 62 of 1958. Therefore, Indonesian citizens who were included in the Dutch colonial era were directly natural-born Indonesian citizens. However, Chinese, Arabic, Dutch, and other descents, since 1946, have been determined by law to become citizens.

Consequently, only their offspring born after the establishment of the 1946 Law are considered a natural-born citizen. Culturally, before independence, the foreign descent group had tried to unite as a part of Indonesia. ${ }^{67}$ However, as has been reviewed the formulation of Article 26 of the 1945 Constitution by BPUPKI, the peranakan group is not referred to as native Indonesians. Hence, they are determined to become Indonesian citizens in 1946 through a passive system.

In subsequent developments, there was a Charter of Approval for the Distribution of Citizens based on the Round Table Conference 1949 between Indonesia and the Netherlands. The Conference concluded the Dutch people's status as Dutch citizens, while Dutch descendants were granted repudiation rights and the option to choose Indonesian citizenship. Likewise, for the Foreign Eastern groups (Chinese and Arab) who are required to take certain juridical actions to become Indonesian citizens, which brought them to legal uncertainty because they use an active system nullifying Law number 3 of $1946 .{ }^{68}$ As a result, many Chinese descendants later chose Chinese citizenship. ${ }^{69}$

On the sidelines of the Asia-Africa Conference, there was an agreement between China and Indonesia. China no longer applied the jus sanguinis principle. It no longer claims all Chinese people in Indonesia as Chinese citizens. Indonesia affirms the active principle so that every Chinese descendant who wishes to become an Indonesian citizen must go through a legal procedure. The agreement was rejected by the Chinese descendant group, namely Indonesian Citizenship Consultative Body (Baperki -Badan Permusyawaratan Kewarganegaraan

67 The efforts of the foreign-descent groups to integrate into Indonesia can be seen in the formation of the Indonesian Chinese Party by Liem Koen Hian, 1932, as well as in the 1934 Indonesian of Arab Descent Youth Pledge and the formation of the Indonesian Arab Party led by AR Baswedan, including also of Dutch descent such as Douwes Dekker and Dahler, who all of them jointly expressed their love for the Indonesian homeland and fought together in the effort for independence. See Benny G. Setiono, Tionghoa di Pusaran Politik, Jakarta: Transmedia, 2008, pp. 525-528; AR Baswedan, Sumpah Pemuda Indonesia Keturunan Arab (1934) (1934), Surabaya: Pers Nasional, 1974, p. 11.

69 At least 630 thousand people of 2.5 million Chinese descents in Indonesia finally chose Chinese citizenship. Some sources say that there are 250-350 thousand. See Melisa Mailoa, "Ke China, Aku Tak Akan Kembali", https://news.detik.com/x/detail/intermeso/20190803/Ke-China,-Aku-Tak-Akan-Kembali/, accessed on October 2020. 
Indonesia), because it triggered denationalization. ${ }^{70}$ In the end, Law number 2 of 1958 confirmed the agreement by providing an opportunity for a two-year process. In practice, the settlement process took much time and is only ended in the New Order Era.

The developments show that the determination of natural-born citizenship for Indonesian citizens of Dutch, Arab, Chinese, and other descendants born before the Citizenship Law 2006 is not easy. The problem that often arises is related to the evidence determining a person as a natural-born citizen. No specific documents are stating that a person is a citizen from birth in various citizenship laws, such as a citizenship certificate in Canada. ${ }^{71}$ The only document that can be used as formal evidence of natural-born citizenship is currently only a birth certificate, which states someone's citizenship at the birth based on Law Number 23 of 2006 on Population Administration along with its implementing regulations, as well as various regulations (reglement/bepalingen) of Dutch civil registration at the time. ${ }^{72}$ From these various provisions, Indonesian citizens of foreign descendants born before the Citizenship Law 2006 and who want to run for president and vice president must show evidence that their parents have become Indonesian citizens, making them born as Indonesians. If the parent is not an Indonesian citizen yet, they are considered a foreigner, not a natural-born citizen.

Besides, people with limited dual-citizenship to 18 years must also be considered as natural-born citizen. However, those nominated to be a presidential candidate may face questions about their allegiance base on the allegiance concept. This has practically never happened in Indonesia. Given the Indonesian constitutional practice, there has never been a president from a mixed marriage. However, in the future, this may happen. Thus, although the natural-born citizens' requirement aims to ensure sufficient allegiance to the state, this requirement still has a weakness because it allows people with limited dual citizenship status to apply for presidential candidates. There are very likely people with limited dual citizenship who do not have a strong attachment to Indonesia, who then become a candidate for President of Indonesia. For this reason, in the future, a genuine link or real and effective citizenship approach is also needed to measure the effectiveness of a limited social bond between dual citizenship and the Indonesian people. ${ }^{73}$

In the United States, which has a dual citizenship policy, natural-born citizenship arises in the Perkins v. Elg case. The Supreme Court affirms that people having dual citizenship caused by being born, in another state, to American parents must be considered natural-born citizens because if foreign citizenship influences American law, especially in terms of determining the president, it is contemplated as

\footnotetext{
Ibid.

71 Ratu Durotun Nafisah, "Penerapan Asas lus Soli Terbatas terhadap Anak dari Pengungsi Rohingya yang Lahir di Indonesia", Thesis, Padjadjaran University, Bandung, 2018, pp. 105-106. Ibid.

73 Susi Dwi Harijanti (et.al), Politik Hukum Kewarganegaraan Indonesia, Jatinangor: Unpad Press, 2020, pp. 103112.
} 
undermining American national sovereignty. ${ }^{74}$ After this decision, no American president has dual citizenship. Even if a presidential candidate has dual citizenship, the enormous public pressure forces him/her to abandon the other citizenship. An example is Ted Cruz, a Republican presidential candidate born in Canada to American parents, who renounced his Canadian citizenship in 2014. ${ }^{75}$

Also, the implications for a natural-born citizen's requirement indicate that accepting another citizenship because of his/her own volition will result in the loss of someone's status as a natural-born citizen. For example, Archandra Tahar, born as a natural-born citizen of Indonesia, had received an American citizen. He cannot be considered a natural-born citizen anymore after he regained his Indonesian Citizenship in 2014. For this reason, citizens having this status cannot be nominated to become President.

\section{b. Other Positions and Husband or Wife of a Presidential Candidate}

The requirement of a natural-born citizen for a presidential candidate should have implications mutatis mutandis to other administrative positions, either executive, legislative, judiciary, and other state institutions because of arguments for the qualifications of an important position that requires single allegiance to the Indonesian state. The case of Archandra Tahar, who was appointed Minister of Energy and Mineral Resources (ESDM) but had American citizenship, is an example of this problem. ${ }^{76}$ Therefore, the requirements regulated in Law number 39 of 2008 on State Ministries are not enough.

A similar thing is applied to the husband or wife of a presidential candidate. Referring to Article 169 of Law number 7 of 2017 on the General Election, which regulates one of the presidential candidate requirements, the Presidential candidate's husband or wife is an Indonesian citizen. From a conceptual perspective, this arrangement can be considered incomplete because the formulation only mentions "Indonesian citizen". From the perspective of perpetual allegiance (loyalty), it still creates the potential disloyalty and even potential betrayal if the presidential candidate's husband or wife is a naturalized Indonesian.

\section{Conclusion}

Based on the analysis, it can be concluded that a natural-born citizen's requirement to become president has two significances. The first is to eliminate racial discrimination, the requirement "the President is a native Indonesian" in the preamended 1945 Constitution. The second is to ensure president's strong allegiance to the Indonesian state, not the foreign state. As for the implications of a natural-

\footnotetext{
Perkins v. Elg (1939) in Jack Maskell, op.cit., p. 41.

75 Nolan Feeney, "Ted Cruz Renounces Newly Discovered Canadian Citizenship", https://time.com/2854513/tedcruz-canadian-citizenship/, accessed on September 2020.

76 Susi Dwi Harijanti, Dwi Kewarganegaraan dan Politik Hukum Kewarganegaraan Indonesia, Paper Presented at the Expertise Body of the DPR RI (Indonesian House of Representatives), Jakarta, September 1, 2016, p. 7.
} 
born citizen, there are also some implications. First, every Indonesian citizen born after the enactment of the Citizenship Law 2006, if since birth has obtained an Indonesian citizen's status, regardless of a particular ethnicity, is considered a natural-born citizen. It includes people born from mixed marriages and people with limited dual citizenship up to 18 years old. Second, Indonesian citizens born before the Citizenship Law 2006 is determined based on the previously applicable regulations: Law number 3 of 1946 and Law number 62 of 1958. It includes the agreements entered into by Indonesia and the Netherland, and China. Third, the requirement of natural-born citizen mutatis mutandis should also be applied to the requirements of other constitutional positions, either executive, legislative, or judiciary, and to the husband or wife of a presidential candidate for allegiance reason.

\section{References}

\section{Books}

A.R. Baswedan, Sumpah Pemuda Indonesia Keturunan Arab (1934), Pers Nasional, Surabaya, 1974.

AB. Kusuma, Lahirnya Undang-Undang Dasar, Badan Penerbit Fakultas Hukum Universitas Indonesia, Jakarta, 2009.

Bagir Manan, Hukum Kewarganegaraan, FH UII Press, Yogyakarta, 2009. , Lembaga Kepresidenan, FH UII Press, Yogyakarta, 2003. , Membedah UUD 1945, Universitas Brawijaya Press, Malang, 2012.

Banakar, Reza and Max Travers, ed., Theory and Method in Socio-Legal Research, Hart Publishing, Oxford \& Portland Oregon, 2005.

Banakar, Reza, Normativity in Legal Sociology: Methodological Reflection in Late Modernity, Springer, Cham, 2015.

Benny G. Setiono, Tionghoa dalam Pusaran Politik, Transmedia, Jakarta, 2008.

Farrand, Max, The Framing of the Constitution of The United States, Yale University Press, New Haven, 1913.

Gouw Giok Siong, Tafsiran Undang-Undang Kewarganegaraan Republik Indonesia, Keng Po, Djakarta, 1960.

Kurniatmanto Sutoprawiro, Hukum Kewarganegaraan dan Keimigrasian Indonesia, Gramedia, Jakarta, 1994.

Mahkamah Konstitusi, Naskah Komprehensif Perubahan Undang-Undang Dasar Negara Republik Indonesia Tahun 1945, Latar Belakang, Proses, dan Hasil Pembahasan, 1999-2002: Buku IV Kekuasaan Pemerintahan Negara, Sekretariat Jenderal Mahkamah Konstitusi, Jakarta, 2010.

Mahkamah Konstitusi, Naskah Komprehensif Perubahan Undang-Undang Dasar Negara Republik Indonesia Tahun 1945, Latar Belakang, Proses, dan Hasil Pembahasan, 1999-2002: Buku VIII Warga Negara dan Penduduk, Hak Asasi Manusia dan Agama, Sekretariat Jenderal Mahkamah Konstitusi, Jakarta, 2010. 
Miles, Matthew B. and A. Michael Huberman, Analisis Data Kualitatif: Buku Sumber tentang Metode-Metode Baru, UI Press, Jakarta, 1992.

Muh. Yamin, Naskah Persiapan Undang-Undang Dasar 1945, Jajasan Prapantja, Jakarta, 1959.

Ratno Lukito, Perbandingan Hukum: Perdebatan Teori dan Metode, Gadjah Mada University Press, Yogyakarta, 2016.

Sudargo Gautama, Warga Negara dan Orang Asing, Alumni, Bandung, 1987.

Susi Dwi Harijanti, (et.al), Politik Hukum Kewarganegaraan Indonesia, Unpad Press, Jatinangor, 2020.

Vogel, Ursula, and Michael Moran (eds), The Frontiers of Citizenship, MacMillan, London, 1991.

Weis, Paul, Nationality and Statelessness in International Law, Sijthoff \& Noordhoff International Publisher, Netherland, 1979.

\section{Other Documents}

BBC News, "Could an American be Canada's Next Prime Minister?, https://www.bbc.com/news/world-us-canada-49938384, accessed on September 2020.

Belot, Henry, "Dual Citizens around the World: These Countries Don't Have the Same Problem We Do", https://www.abc.net.au/news/2017-11-07/dualcitizenship-around-the-world/9126438, accessed on September 2020.

CBC News, "The Role of Canada's Governor General", https://www.cbc.ca/news/canada/the-role-of-canada-s-governor-general-

1.907373, accessed on September 2020.

Constitute Project, "The World's Constitutions to Read, Search, and Compare", https://www.constituteproject.org/search?lang=en, accessed on JuniSeptember 2020.

Feeney, Nolan, "Ted Cruz Renounces Newly Discovered Canadian Citizenship", https://time.com/2854513/ted-cruz-canadian-citizenship/, accessed on September 2020.

French Embassy in the United Kingdom, "Five Things You Need to Know about the French Presidential Election", https://uk.ambafrance.org/Five-things-you-needto-know-about-the-French-presidential-election, accessed on September 2020.

Friedman, Lawrence, "An Idea Whose Time Has Come-The Curious History, Uncertain Effect, and Need for Amendment of the "Natural Born Citizen" Requirement for the Presidency", Saint Louis University Law Journal, Vol. 52, No. 1, 2007.

Henderson, Andrew, "8 Countries Where You Can Become President With a Second Passport", https://nomadcapitalist.com/2017/12/01/countries-president-withsecond-passport/, accessed on September 2020.

Ihsan Dalimunthe, "Yusril Bersikukuh Ahok Lahir sebagai WNA dan Tak Bisa Nyapres", https://www.cnnindonesia.com/nasional/20180403214308-32- 
288039/yusril-berkukuh-ahok-lahir-sebagai-wna-dan-tak-bisa-nyapres, accessed on September, 2020.

lil Askar Monza, "Yang Bikin Ahok Mustahil Jadi Calon Presiden Menurut Yusril Ihza", https://nasional.tempo.co/read/1075114/yang-bikin-ahok-mustahil-jadi-calonpresiden-menurut-yusril-ihza/full\&view=ok, accessed on September, 2020.

Imam Hamdi, "Sebut Ahok Tak Bisa Jadi Presiden, Yusril Pertanyakan Surat Terbuka Harry Basuki", https://metro.tempo.co/read/1076035/sebut-ahok-tak-bisa-jadipresiden-yusril-pertanyakan-surat-terbuka-harry-basuki/full\&view=ok, accessed on September, 2020.

Maskell, Jack, "Qualification for President and the "Natural Born" Citizenship Eligibility Requirement", Congressional Research Service Report for Congress, Washington, D. C., 2011.

Mei Susanto, "Wacana Mengembalikan Syarat Presiden Orang Indonesia Asli Ditinjau dari Perspektif Ketatanegaraan", Jurnal Ilmiah Kebijakan Hukum, Vol. 11, No. 2, 2017.

Melisa Mailoa, "Ke China, Aku Tak Akan Kembali", https://news.detik.com/x/detail/intermeso/20190803/Ke-China,-Aku-Tak-AkanKembali/, accessed on Oktober 2020.

Nelson, Michael, "Constitutional Qualification for President", Presidential Studies Quarterly, Vol. 17, No. 2, 1987.

Nur'asia, Aminuddin Kasim and Mohammad Tavip, "Status Kewarganegaraan Anak yang Lahir dari Perkawinan Beda Kewarganegaraan (Telaah Wacana Gloria Natapradja Hamel)", Tadulako Master Law Journal, Vol. 2, No. 1, 2019.

Ratu Durotun Nafisah, "Penerapan Asas Ius Soli Terbatas terhadap Anak dari Pengungsi Rohingya yang Lahir di Indonesia", Thesis, Universitas Padjadjaran, Bandung, 2018.

Skinner, Richard, "The Constitution's "Natural-Born" Defect", https://www.vox.com/mischiefs-of-faction/2019/4/15/18308338/natural-borncitizen-us-president, accessed on September 2020.

Susi Dwi Harijanti, Dwi Kewarganegaraan dan Politik Hukum Kewarganegaraan Indonesia, Paper Presented at the Expertise Body of the DPR RI (Indonesian House of Representatives), Jakarta, 1 September 2016.

Susi Dwi Harijanti, Rahayu Prasetianingsih, and Bilal Dewansyah, "Politik Hukum Kewarganegaraan Indonesia", Research Report of the Faculty of Law, Bandung, 2007.

Tirto.id, "Ma'ruf Amin", https://tirto.id/m/maruf-amin-bM, accessed on September 2020.

Tundjung Herning Sitabuana, "Indonesian Chinese Diaspora, Dual Citizenship and Indonesian Development", Constitutional Review, Vol. 1, No. 1, 2015. 


\section{Legal Documents}

The 1945 Constitution of the Republic of Indonesia [Undang-Undang Dasar Negara

Republik Indonesia Tahun 1945].

Indische Staatsregeling [IS].

The Code of Private International Law of 1928 [Bustamente Code].

The 1787 Constitution of the United States.

The Law Number 3 of 1946 on Citizenship and Resident of Indonesia [UndangUndang Nomor 3 Tahun 1946 tentang Warga Negara dan Penduduk Negara].

The Law Number 62 of 1958 on Citizenship of the Republic of Indonesia [UndangUndang Nomor 62 Tahun 1958 tentang Kewarganegaraan Republik Indonesia].

The Law Number 12 of 2006 on Citizenship of the Republic of Indonesia [UndangUndang Nomor 12 Tahun 2006 tentang Kewarganegaraan Republik Indonesia].

The Law Number 23 of 2006 on Population Administration [Undang-Undang Nomor 23 Tahun 2006 tentang Administrasi Kependudukan]. 